\title{
Accident Tolerant Clad Material Modeling by MELCOR: Benchmark for SURRY Short Term Station Blackout
}

\author{
Jun Wang ${ }^{1 *}$, Mckinleigh Mccabe ${ }^{1}$, Lei Wu$^{2}$, Xiaomeng Dong ${ }^{1}$, Xianmao Wang $^{2}$, \\ Christopher Haskin Troy ${ }^{1}$, Michael L. Corradini ${ }^{1 *}$ \\ ${ }^{1}$ College of Engineering, the University of Wisconsin-Madison, Madison, 53706, Unite States \\ ${ }^{2}$ Institute of Nuclear and New Energy Technology, Tsinghua University, Beijing, 100084, China
}

Corresponding Author

Jun Wang, Michael L. Corradini

College of Engineering, the University of Wisconsin-Madison, Madison, 53706, Unite State

Tel \& Fax +1 6083350866, 6082631648

Email: jwang564@wisc.edu; corradini@engr.wisc.edu

(C) 2017. This manuscript version is made available under the Elsevier user license 


\begin{abstract}
:
Accident tolerant fuel and cladding materials are being investigated to provide a greater resistance to fuel degradation, oxidation and melting if long-term cooling is lost in a Light Water Reactor (LWR) following an accident such as a Station Blackout (SBO) or Loss of Coolant Accident (LOCA). Researchers at UW-Madison are analyzing an SBO sequence and examining the effect of a loss of auxiliary feedwater (AFW) with the MELCOR systems code. Our research work considers accident tolerant cladding materials (e.g., FeCrAl alloy) and their effect on the accident behavior. We first gathered the physical properties of this alternative cladding material via literature review and compared it to the usual zirconium alloys used in LWRs. We then developed a model for the Surry reactor for a Short-term SBO sequence and examined the effect of replacing FeCrAl for Zircaloy cladding. The analysis uses MELCOR, Version 1.8.6 YR, which is developed by Idaho National Laboratory in collaboration with MELCOR developers at Sandia National Laboratories. This version allows the user to alter the cladding material considered, and our study examines the behavior of the FeCrAl alloy as a substitute for Zircaloy. Our benchmark comparisons with the Sandia National Laboratory's analysis of Surry using MELCOR 1.8.6 and the more recent MELCOR 2.1 indicate good overall agreement through the early phases of the accident progression. When FeCrAl is substituted for Zircaloy to examine its performance, we confirmed that FeCrAl slows the accident progression and reduce the amount of hydrogen generated. Our analyses also show that this special version of MELCOR can be used to evaluate other potential ATF cladding materials, e.g., $\mathrm{SiC}$ as well as innovative coatings on zirconium cladding alloys, $\mathrm{Cr}, \mathrm{ZrSi}, \mathrm{TiAlC}$, and TiSiC. This ATF performance analysis platform will also be used to support experimental work underway in our Integrated Research Project.
\end{abstract}

Key Words: Accident Tolerant Fuel, Fuel Performance Modeling, MELCOR, Benchmark, Short Term Station Black Out (STSBO), FeCrAl 


\section{Introduction}

As a result of the great earthquake of east Japan, along with the catastrophic tsunami, the Fukushima Daiichi BWR plants were severely damaged. These events generated serious discussion in the United States (Carmack et al., 2013) to develop fuel and cladding improvements that would be more accident tolerant and give operators more time to employ mitigation measures during accidents to minimize core degradation, fuel failure and fission product release. This is the objective of the Accident Tolerant Fuels, ATF, program. A research team (MIT, UW-Madison, Texas A\&M, AREVA and Westinghouse) supported by DOE Integrated Research Project (IRP) is focused on development of accident tolerant fuel-clad options for near term applications. As part of this work, fuel performance modeling for a range of accidents is being analyzed using the MELCOR systems code at the University of Wisconsin-Madison. This work initially has used the Surry nuclear plant as its model plant and the Short Term Station Blackout (STSBO) as the postulated accident to consider. This version allows the user to alter the cladding material considered, and our study examines the behavior of the FeCrAl alloy (Ott et al., 2014; Wu et al., 2015) as a substitute for Zircaloy. Among all the parameters that characterize the clad material performance, the hydrogen generation history is a key indicator of core degradation. This work examines the effect of substituting FeCrAl alloy for Zircaloy clad. The technique used could be a useful systems analysis approach to examine other potential ATF clad materials analysis; e.g., SiC (Merrill and Bragg-Sitton, 2013a; Pint et al., 2013; Wang et al., 2015b).

\section{Literature Review of Recent ATF Developments}

Zinkle et al (2014) provided a general overview of core degradation processes under coolant-limited conditions. As one can see from the first phase of the accident, the loss of cooling capability and the water coolant inventory results in the depressurization of the primary system (Wang et al., 2012). This depressurization can span several seconds for a large-break LOCA, several minutes for a small-break LOCA, and several hours for an SBO (Wang et al., 2015a). One can also see from the lead-up phase, decay heat and the stored energy cannot be rejected to a heat sink, which causes the fuel and clad temperature to increase. Zircaloy clad can fail if high enough temperatures are reached, 
and this can also generate significant hydrogen from oxidation ( 1500 K; Massey et al., 2016). However, if ATF clad material is used, these effects could be significantly delayed or, potentially, avoided (Farmer et al., 2014).

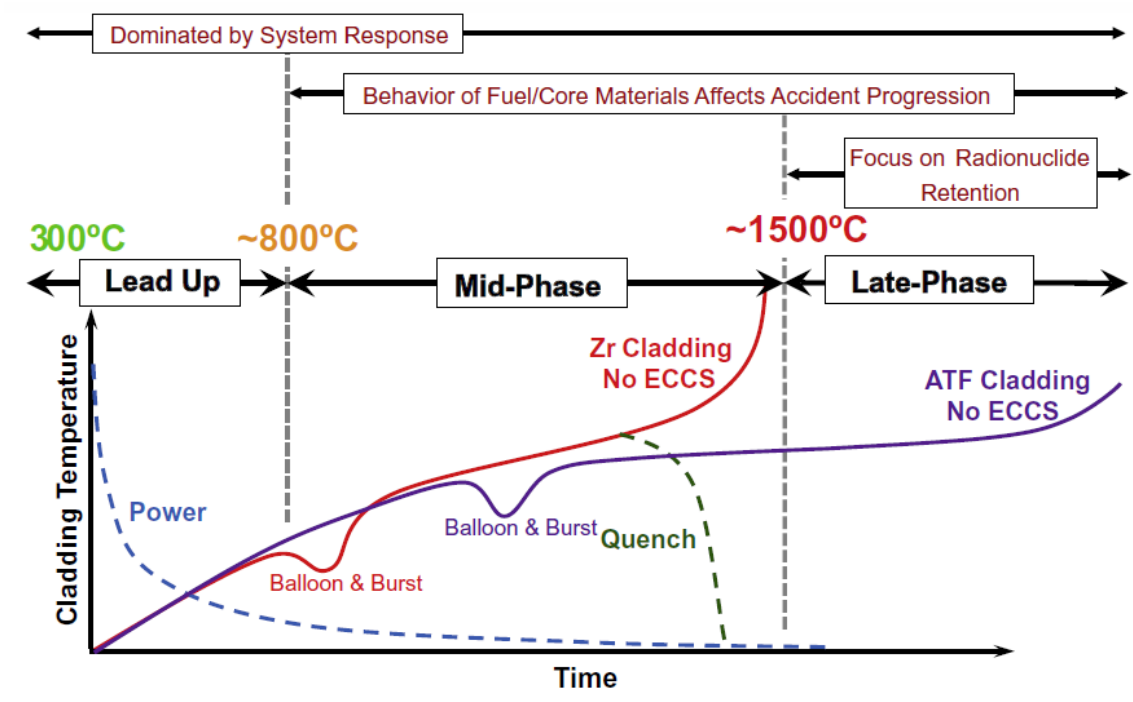

Fig. 1 Core Degradation Processes under Coolant-limited Conditions (Zinkle et al., 2014)

Recently, many projects focused on the ATF objective have been begun at national laboratories, at universities, in the nuclear industry, with international partners, and with the Nuclear Regulatory Commission (Bragg-Sitton, 2014) (Carmack and Goldner, 2014). In order to provide development of ATF options for present day applications, we are part of a research team led by MIT to examine potential ATF candidates for enhanced accident tolerant fuel and clad. Group members include MIT, UW-Madison, TAMU, AREVA, and Westinghouse.

To cultivate the accident tolerant reactor concept, which could absorb the ATF concept from other teams, the Georgia Institute of Technology was asked to conduct an integrated research project (IRP) separately (Youinou and Sen, 2013). Another IRP team from the University of Illinois and the University of Manchester is investigating two pathways in order to improve the modification of monolithic zircaloy cladding as the foundation of ATF cladding (Bragg-Sitton, 2014). Utilizing various architectures of ceramic coatings, 
including coating zirconium alloys used by University of Tennessee, provides a good way to observe the surface modifications of Zr-alloy cladding (Terrani et al., 2013).

In the field of the development of high-density ceramic fuels, Los Alamos National Laboratory (LANL) has achieved the main development in the field of advanced metallic alloys which are corrosion-resistant, act as cladding, and can play an important role in many other ATF concepts (Brown et al., 2014). At the same time, Oak Ridge National Laboratory (ORNL) focuses on high-temperature, oxidation-resistant steel cladding and the microencapsulated (TRiSO-based) fuel field (Lauf et al., 1984). Specifically, ORNL has done a tremendous amount of work on FeCrAl (Ott et al., 2014; Wu et al., 2015). With regard to the U-Mo fuel in LWR, Pacific Northwest National Laboratory is deeply involved. Researchers at PNNL hope to develop a metallic fuel with higher power density for light water reactors (LWR). ATF cladding materials are being considered in cooperation with these ATF metal fuels (Einziger, 1988). The basic program has elements in co-extruded U-Mo metallic fuel material to improve corrosion resistance. At AREVA, the enhanced ATF concept, still under development, is being used to improve performance in both normal and abnormal conditions that go beyond the design basis, aiming to ensure the competitive cost of the ATF. The idea of replacing Zircaloy clad with an advanced steel can offer more benefits for beyond design-basis accidents. An ATF material with improved economics in normal operation and containment of all fuel fission products during a beyond design-basis accident is also being developed by a team at Westinghouse Electric Company.

Our focus at UW-Madison is on cladding systems using advanced materials, such as FeCrAl (Ott et al., 2014), Mo-core composite and ceramics such as $\mathrm{SiC}$ and $\mathrm{SiC}$ composites (Stempien, 2011), and Zircaloy-based alloys with advanced coatings (BraggSitton, 2014). In this work, we use the MELCOR code as part of a methodology that examines the effect of such clad materials on severe accident progression: e.g., $\mathrm{H}_{2}$ generation as a figure of merit. 
UW-Madison is using a special version of MELCOR, MELCOR-1.8.6 (YR). This version allows the user to alter the cladding material considered, and our study examines the behavior of the FeCrAl alloy as a substitute for Zircaloy. (Merrill and Bragg-Sitton, 2013b) We have chosen the Surry Nuclear plant (SURRY) as the candidate reactor system for this analysis (Bixler et al., 2008), and short term station blackout is the first scenario considered (Carbajo, 1994). These choices allow us to benchmark our analysis with past published work on SOARCA using MELCOR-1.8.6 (Gauntt, 2005) and the SOARCA uncertainty analysis with MELCOR-2.1 (Bixler et al., 2008). The criteria to be considered for comparison between these analyses are the event timing, the system parameter history (e.g., temperature), and hydrogen generation.

\section{MELCOR Description, STSBO Description, and Nodalization}

The MELCOR code is a fully integrated engineering-level systems code, which models the development of severe accidents in a light water reactor. It replaced the Source Term Code Package and is a second-generation plant risk assessment tool. MELCOR can also be used to analyze design-basis accidents for advanced plant applications. Using MELCOR allows us to compare different potential clad materials, and examine the advantages and disadvantages of those clad materials during an accident progression.

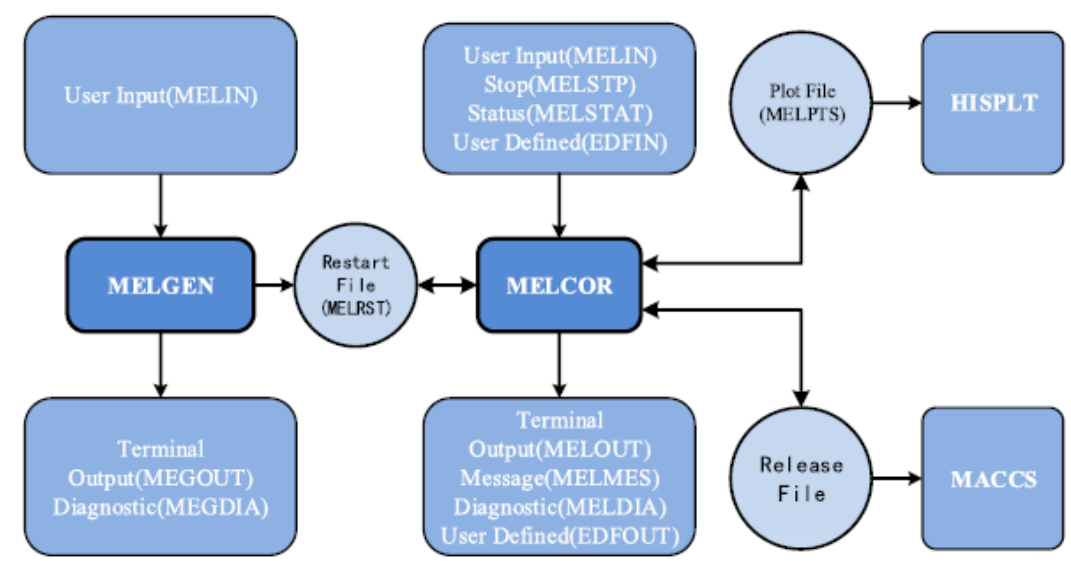

Fig. 2 Simple Chart of MELCOR Calculation (Gauntt, 2005; Wang et al., 2014)

The MELCOR code models all related plant systems, plant phenomena, and generating transients in a wide ranged system: thermal hydraulic performance, thermomechanical interactions, and chemical interactions. MELCOR consists of a variety of parts, which are 
displayed in Fig. 1. MELGEN controls the basic pre-processing input data, while the main MELCOR program is in charge of calculations. The rest of the relevant parts of the code comprise the PLOT program and the MACCS program, which is designed to analyze the off-site radiological consequences. There are a variety of code packages (COR, CVH, and FL) used to model different portions of the reactor.

A Short Term Station Black Out (STSBO) is a particular scenario within the general accident category of a station black out. The main difference between short term station black out and long term station black out is that there is no auxiliary feedwater operation in the former. For the STSBO severe accident, we could summarize it as in Table 1:

Table 1: Accidents Associated with Short Term Station Black Out (Bixler et al., 2008)

\begin{tabular}{ll}
\hline Component & Status \\
\hline RCS (Reactor Cooling System) & Intact \\
CTMT (Containment) & Intact \\
AC POWER & Failed \\
DC POWER & Failed \\
HHSI (High Head Safety Injection) & Failed \\
LHSI (Low Head Safety Injection) & Failed \\
CCW (Component Cooling Water) & Failed \\
CTMT SPRAY & Failed \\
FAN COOLER & Failed \\
\hline
\end{tabular}

The nodalization scheme is shown in Fig. 3 and mimics that used in the SOARCA analyses. As seen in this figure, the core of the SURRY plant is separated into 5 rings in the radial direction, and 10 nodes in an axial direction. The lower plenum and dome are also divided into several nodes. In the top dome, some nodes are coincident. This situation will influence the results of the reactor pressure vessel water level. There are three steam generator loops in this plant: even though only one loop is shown. 


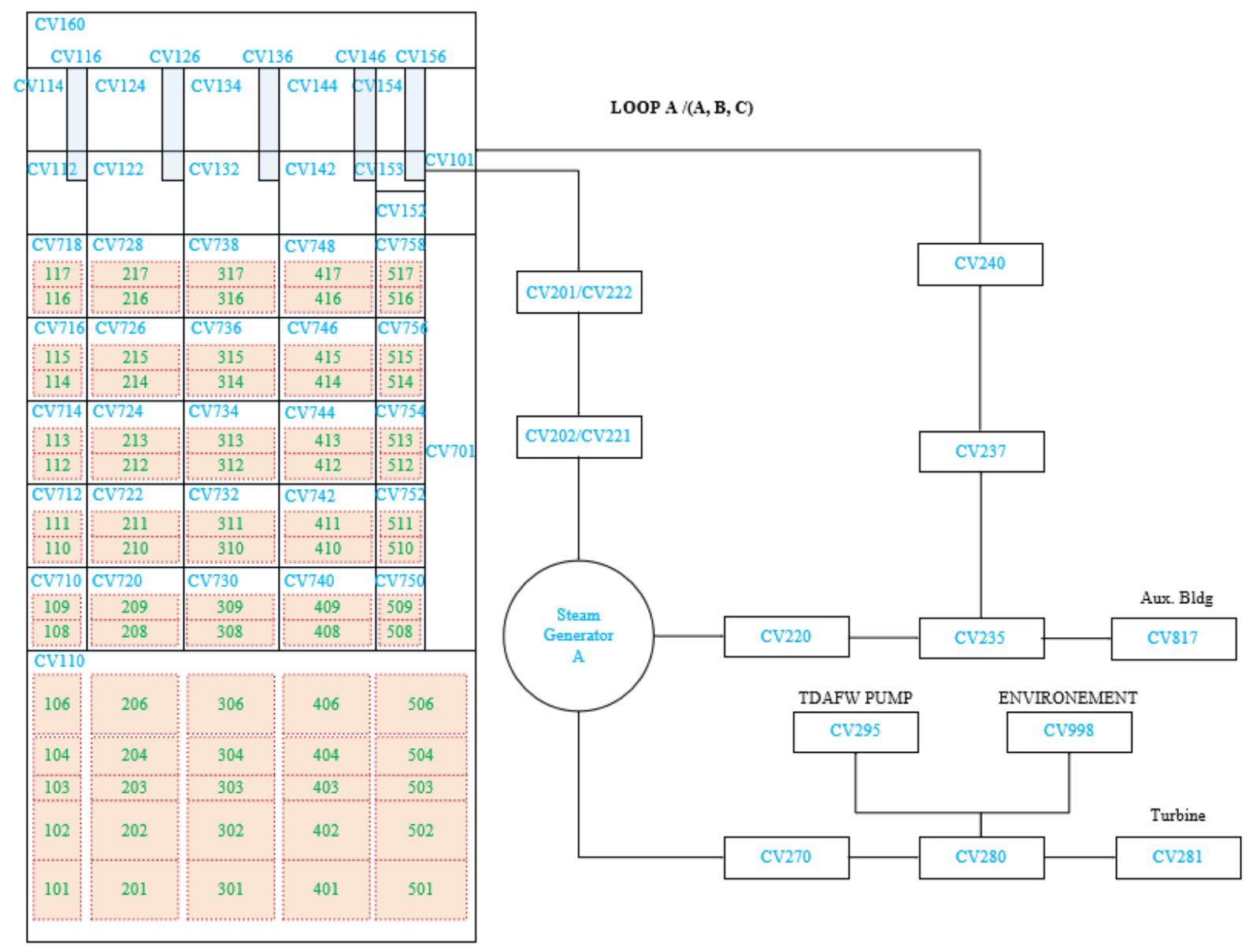

Fig. 3 Nodalization Scheme of the SURRY Plant Core

\section{SURRY Benchmark Simulation and Comparison}

Table 2 presents the events occurrence and timing of the STSBO. The left side shows the calculation results and the right side shows SANDIA's results. Table 2 provides a timing comparison of key events between the NUREG/CR-7110 Volume 2 SOARCA STSBO calculation and the new MELCOR 2.1 calculation. The timings are close to each other until the start of the core collapse. In particular, the timing to RCP pump seal failure and hot leg nozzle failure are nearly identical. The phenomena following the hot leg creep rupture failure are particularly complex, and there were modeling changes made which led to differences in timing. The sharp depressurization of the primary system led to a rapid accumulator water injection into the hot core. Even though the fuel rods kept vertical when the hot leg failed, there was cladding failure and heavy oxidation. 
Furthermore, some regions remained in film boiling. The core degradation proceeded as the accumulator water boiled away.

Table 2: Event Time of Short Term Station Blackout (Bixler et al., 2008)

\begin{tabular}{|c|c|c|c|}
\hline EVENT DESCRIPTION & $\begin{array}{l}\text { UW } \\
\text { Time (h) }\end{array}$ & $\begin{array}{l}\text { Comparison } \\
\text { Time (h) }\end{array}$ & EVENT DESCRIPTION \\
\hline $\begin{array}{l}\text { Initiating Event: Station Blackout-loss of all onsite and } \\
\text { offsite AC and DC power }\end{array}$ & 00:00 & 00:00 & $\begin{array}{l}\text { Initiating Event: Station Blackout-loss of all } \\
\text { onsite and offsite AC and DC power }\end{array}$ \\
\hline $\begin{array}{l}\text { RCS Intact, CTMT Intact, RCP seal cooling fails, TD- } \\
\text { AFW fails }\end{array}$ & 00:00 & 00:00 & $\begin{array}{l}\text { RCS Intact, CTMT Intact, RCP seal cooling } \\
\text { fails, TD-AFW fails }\end{array}$ \\
\hline ECCS SIGNAL & $00: 42$ & - & \\
\hline SURGE TANK RUPTURE DISKS FAILED & $01: 48$ & $01: 46$ & PRT rupture disk opens \\
\hline Loop C Leakage at $182 \mathrm{gpm}$ & $02: 48$ & $02: 45$ & RCP seal failures \\
\hline Loop C leakage at $23 \mathrm{gpm}$ & $02: 48$ & $02: 45$ & RCP seal failures \\
\hline GAP RELEASE IN ROD GROUP 1 & 03:00 & $02: 57$ & First fission product gap releases \\
\hline Hot Leg Nozzle (Loop C) Fails Due to Creep Rupture & $03: 42$ & $03: 45$ & $\begin{array}{l}\text { Creep rupture failure of the } \mathrm{C} \text { loop hot leg } \\
\text { nozzle }\end{array}$ \\
\hline $\begin{array}{l}\text { A DEFLAGRATION HAS STARTED IN VOLUME } \\
10\end{array}$ & $03: 42$ & - & \\
\hline Accumulator Injection Begins & $03: 42$ & $03: 45$ & Accumulators start discharging \\
\hline Accumulators Empty & 03:48 & $03: 45$ & Accumulators are empty \\
\hline CORE SUPPORT STRUCTURE (PLATEG) HAS & & & \\
\hline FAILED IN CELL 107 & 04:18 & $04: 23$ & First failure of the core support plate \\
\hline START OF DEBRIS QUENCH IN RADIAL RING 1 & 04:18 & - & \\
\hline END OF DEBRIS QUENCH IN RADIAL RING 1 & $06: 42$ & $06: 39$ & Lower plenum dry-out \\
\hline $\begin{array}{l}\text { THE LOWER HEAD IN SEGMENT } 2 \text { OF RING } 2 \text { HAS } \\
\text { FAILED FROM THRU-WALL YIELDING }\end{array}$ & 07:06 & $07: 16$ & $\begin{array}{l}\text { Vessel lower head failure by creep rupture } \\
07: 16\end{array}$ \\
\hline BEGINNING OF DEBRIS EJECTION TO CAVITY & 07:06 & $07: 16$ & Debris discharge to reactor cavity \\
\hline CAVITY 0 WAKING UP & 07:06 & $07: 27$ & Cavity dry-out \\
\hline
\end{tabular}

The benchmark of the SURRY plant is presented in Fig.4 to Fig.12. All the UW calculations are compared to SANDIA's report (Bixler et al., 2008). Fig. 4 shows how primary and secondary pressure systems change in the first eight hours after the blackout. At the beginning, the SURRY plant scrams successfully due to the loss of core power. The valves of the main steam line isolation and containment isolation respond by closing. 
Additionally, the main feed-water pumps and the coolant pump trips reactor coolant trip. The normal heat removal mechanism in the primary system would be unavailable unless the main steam lines open. As a result, the pressure in both systems rises. In the secondary pressure system, when the pressure gets close to the closing pressure, the relief valves would open and close.

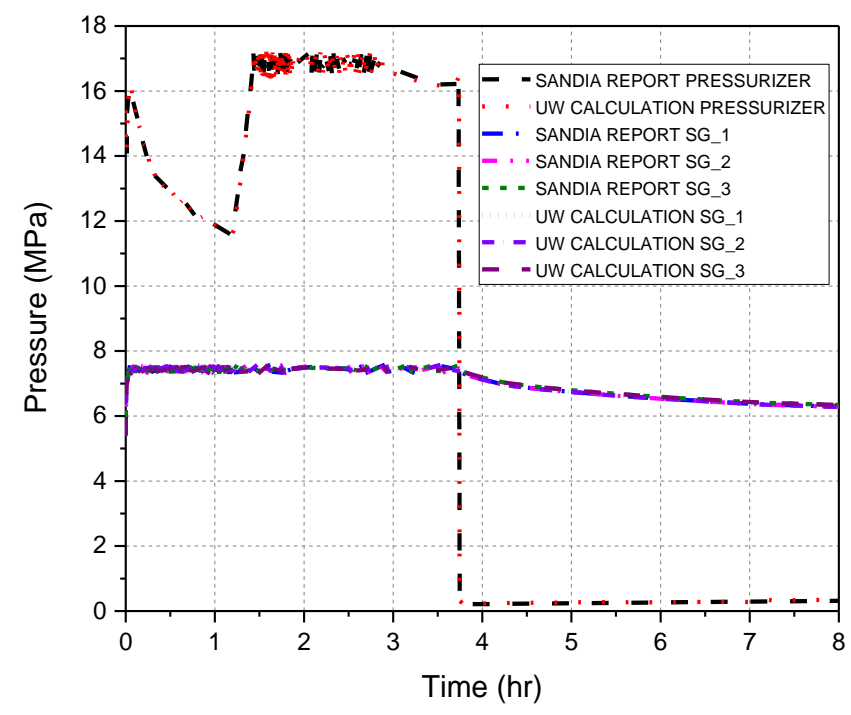

Fig. 4 Primary and Secondary Pressure

As shown in Fig. 4, at 1 hour 16 min, the water inventory in the steam generators 2 th loop is boiled away completely. Even though the relief valves of the steam generators keep cycling and releasing steam there is not enough heat removal equipment, and the pressure in the primary system rapidly comes to the valve opening pressure. The pressurizer valves open to discharge energy, which is beyond the criterion. The pressurizer relief valve flow gives rise to a stabilized reduction in the primary system coolant inventory. On account of all the feed-water's complete loss at the beginning, the steam generators' water inventory decreases radically and is boiled away at 1 hour 16 min. Even though the relief valves of the steam generators keep operating and releasing steam, there is no adequate associated heat removal to keep the pressure. As result, the pressure in the primary system increases rapidly to the opening pressure of the pressurizer's safety relief valve. Excess energy is removed by the pressurizer safety valves. 
The coolant inventory in the primary system decreases as a result of the pressurizer relief valve flow, as shown in Fig. 5. While the pressurizer safety valves work the coolant goes out with the steam, so the vessel water level constantly decreases after 1 hour and 45 minutes. An extra water injection takes place at 4 hours; thus, there is a peak in water level at that time. Finally, all the vessel water dries up.

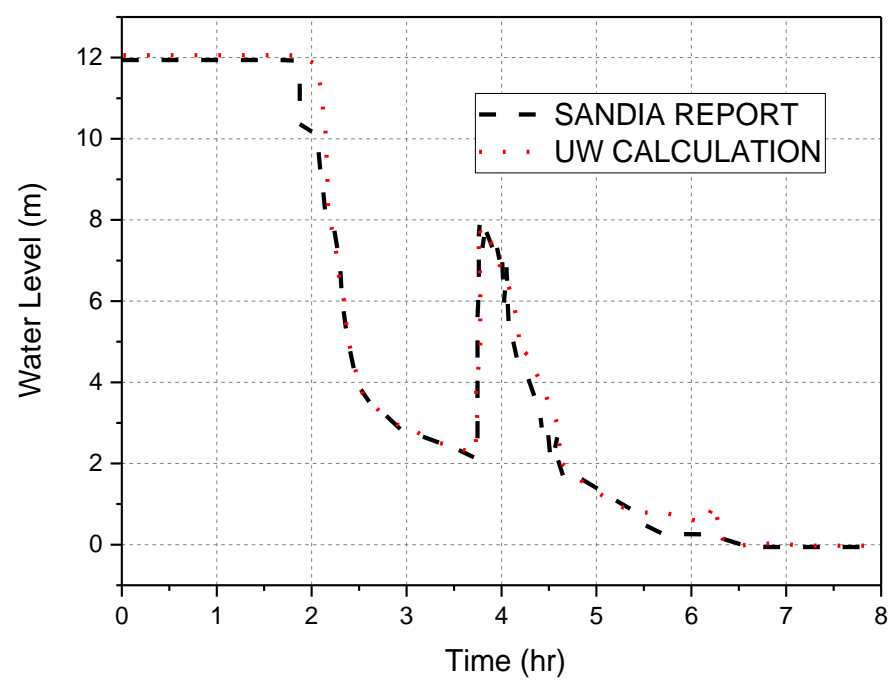

Fig. 5 Comparison of Reactor Vessel Water Level

On account of all the feed-water's complete loss at the beginning of the transient, the steam generators' water inventory decreases radically and is boiled away by 1 hour 16 minutes (see Fig. 6). This means there is still heat removal between 0 hour and 1 hour 16 minutes. After that, the vessel will finally lose heat removal abilities. 


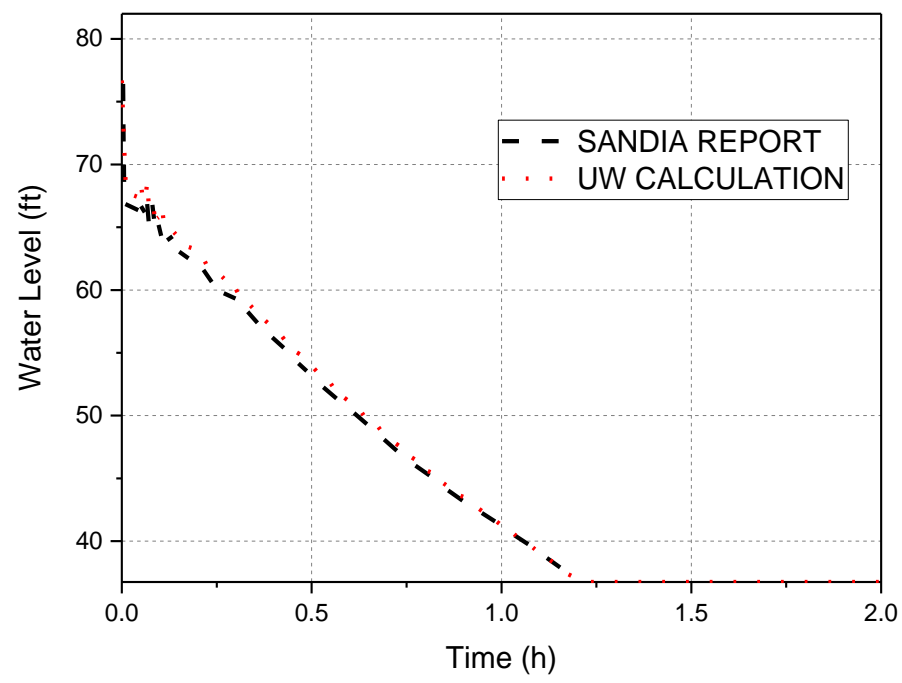

Fig. 6 SG Down-comer Water Level

Even though the relief valves of the steam generators continue cycling and releasing steam there is not enough heat removal. The primary system rapidly rises up to the opening pressure of the pressurizer safety relief valve. Excess energy is removed by opening and closing the safety valves on the pressurizer. The primary system coolant inventory goes through a steady reduction because of the pressurizer relief valve flow (see Fig. 7). When the hot leg nozzle fails, the large hole depressurizes the RCS as soon as it opens (like a large break LOCA). At low pressure, complete accumulator injection is permitted by the RCS depressurization (water level rises at 3 hours 45 min on Fig. 7). Even if the water level is above the reactor core, the hottest fuel regions remain in film boiling and continue heating and degrading in the core. On the outer ring of the core, the lower temperature regions are water covered, and these regions are reheated when the water level falls below the core region. 


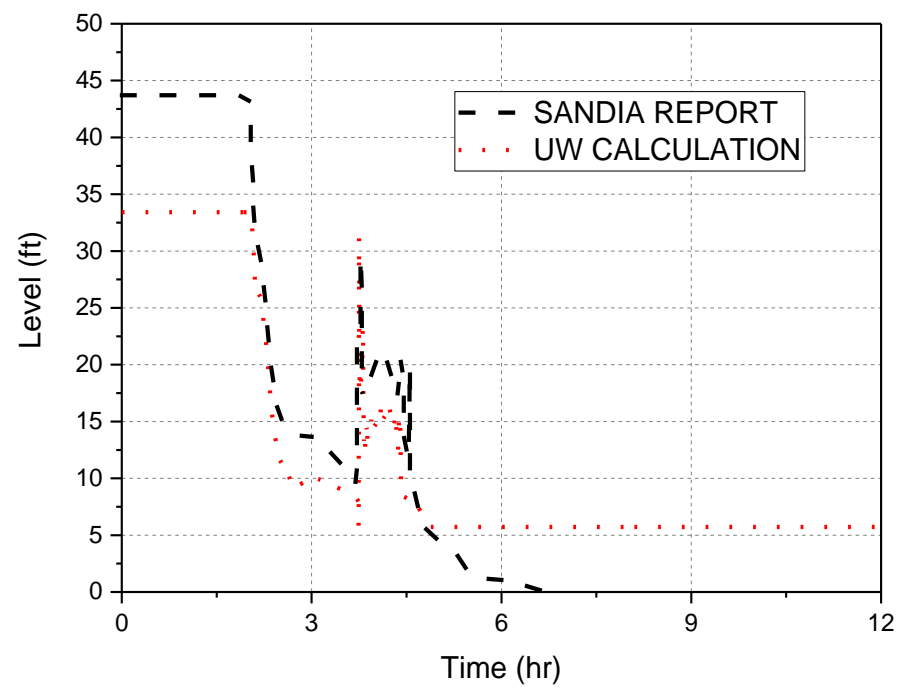

Fig. 7 RPV Down-comer Water Level

At 2 hours $19 \mathrm{~min}$ the fuels start to uncover (see Fig. 8). As fission products start to release from the fuel as the cladding of the fuel fails at 2 hours $59 \mathrm{~min}$. The fuel rods begin to degrade above $2400 \mathrm{~K}$ when the cladding's oxidized shell is broken by the molten zirconium. Since the remaining oxide shell is thermo-mechanically weak at high temperatures they eventually collapse. Fig. 8 shows that the molten eutectic fuelzirconium oxide is the highest temperature fuel-debris at about $2800 \mathrm{~K}$.

There is an in-vessel natural circulation flow in the upper plenum which develops between the cooler structures and the hot fuel in the core following the uncovering of the fuel. Hot gas moves out of the center of the core and then goes up to the upper plenum. Then, it goes back to the cooler peripheral sections of the core. Between the steam generators and the hot gases in the vessel, a natural circulation circuit is developed as well. Hot gas moves in the top of the hot leg and the steam generators in the vessel. It takes up nearly half of the tubes and comes through the steam generators, then comes back through another part of the tubes. The heat generated from the gas exiting the vessel is absorbed by the hot leg piping, steam generator tubes, and the large mass of the hot leg nozzle. The cooler gas leaves the steam generator through the hot leg back to the vessel. 


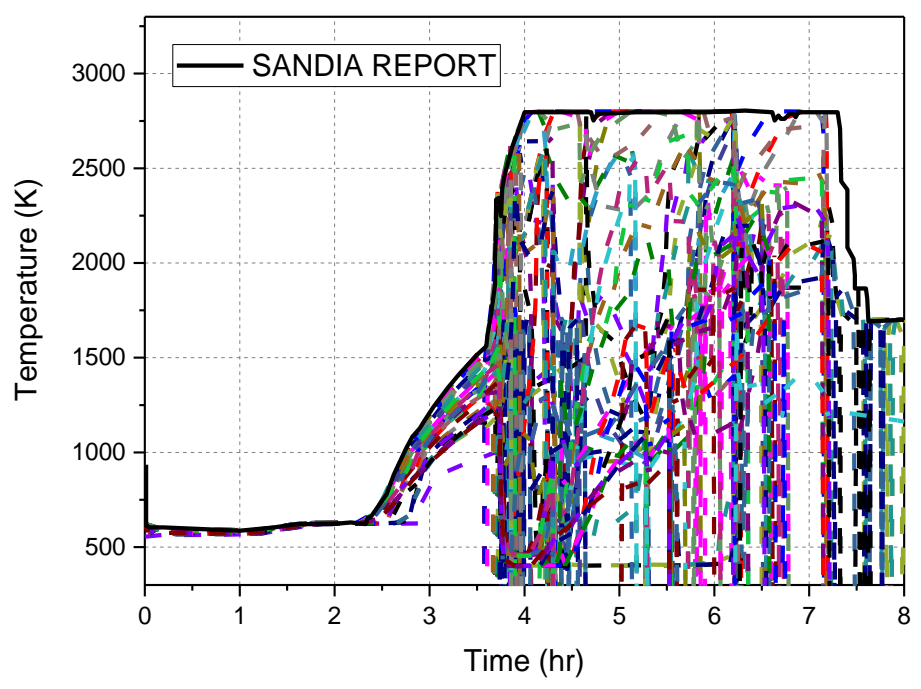

Fig. 8 Peak Temperature of the fuel-clad debris

When the hot leg nozzle fails the large hole depressurizes the RCS as soon as it opens. At low pressure, complete accumulator injection is permitted by the RCS depressurization (water level shows as Fig. 5 and Fig. 7). Even if the water level comes up beyond the reactor core the regions of the highest temperature fuel continue boiling, heating, and degrading in the core (see Fig. 8). The regions on the outer ring of the core in the lower temperature region are quenched, but they would reheat if the water level fell below the core region.

The injected water is boiled away by the fuel decay heat by 3 hours 45 minute. In the core center, a large debris bed is shaped by 4.3 hours. The debris keeps expanding until 5.8 hours when the fuel burns out of the core and falls to the core support plate. The core support plate fails because of the hot debris and falls on the support plate at the lower core at 6.6 hours. The debris bed is relocated with the failure of the lower core support plate. The little remaining water is quickly boiled in the lower head, which is heated by the hot debris, and the temperature exceeds the stainless steel melting temperature (1700 K). Following the creep rupture failure criterion, the lower head fails at 7 hours 16 min when it receives the transfer heat. 


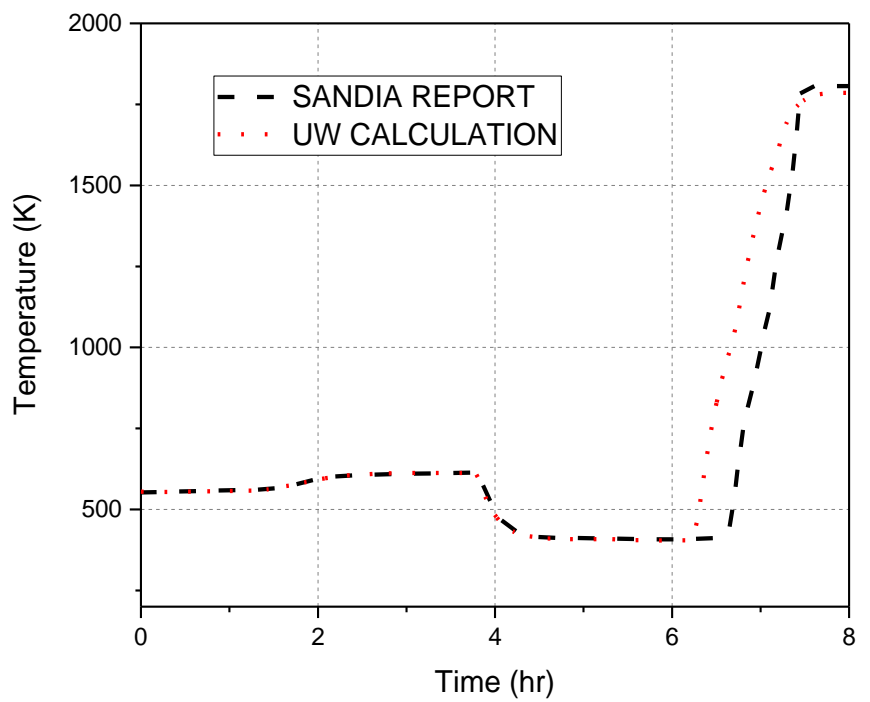

Fig. 9 Lower Head Temperature

After the RPV lower head failure, the hot debris falls from the lower vessel (see Fig. 10) into the reactor cavity. The water in the reactor cavity will be boiled away, and the hot debris will meet the concrete at 7.5 hours.

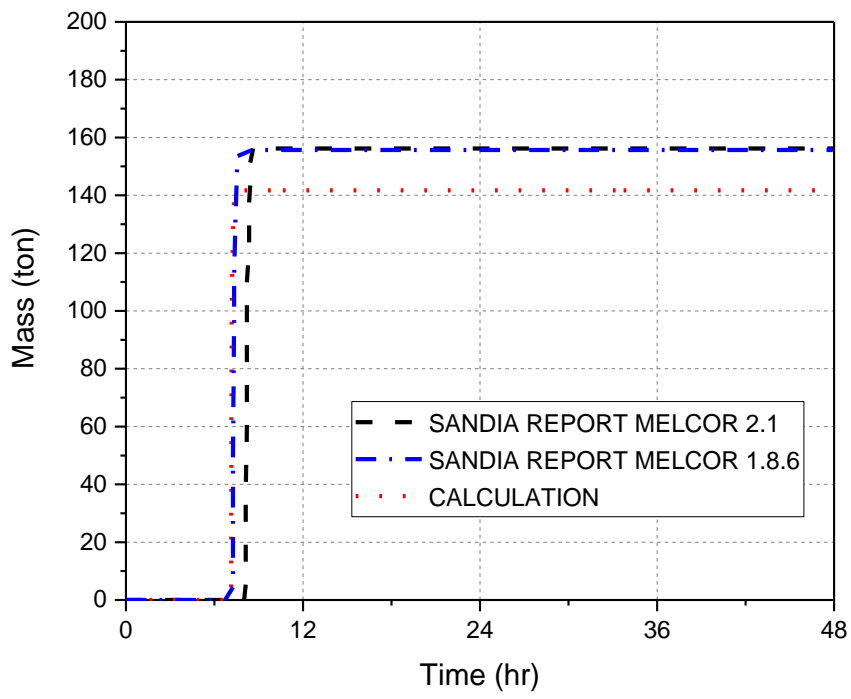

Fig. 10 Debris Mass through Vessel 


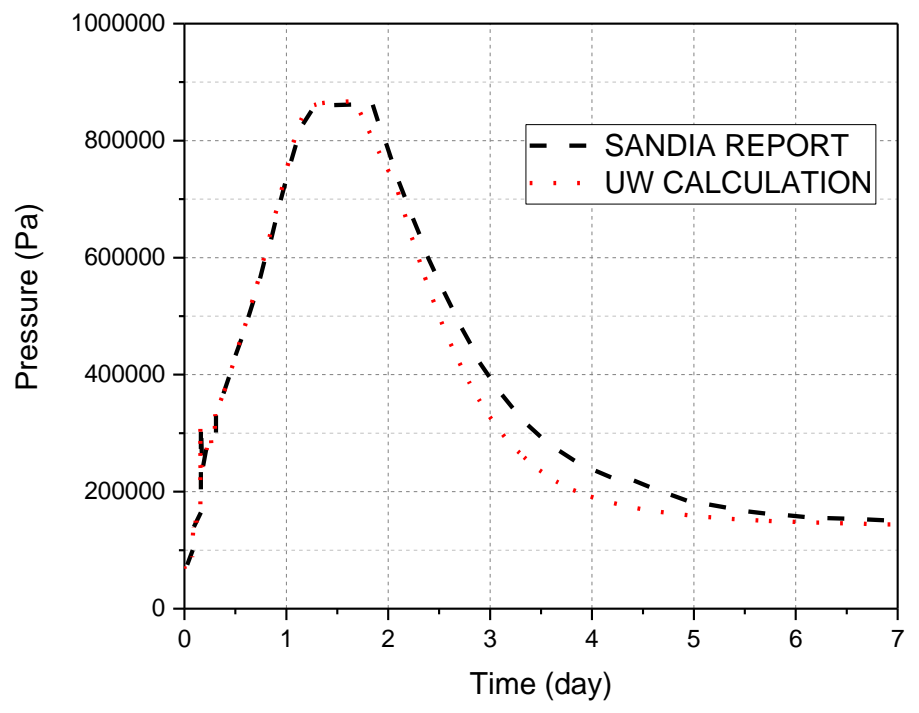

Fig. 11 Containment Pressure

For the remainder of the calculation, the ex-vessel core-concrete interaction $(\mathrm{CCI})$ produced non-condensable gases. In addition, the hot gases exiting the reactor cavity from airborne and settled fission products steadily evaporated the water on the containment floor outside the reactor cavity from 7.3 hour to 44 hours. The containment was pressurized by steam generation and the resultant non-condensable gas (see Fig. 11). The liner tearing leads to the failure of the containment at 25.5 hours, which occurs in the middle of the containment near the containment equipment hatch. The containment would not stop pressurizing until the non-condensable gas and steam generation is balanced by the leakage flow. At 44 hours, the water on the floor has evaporated entirely. Since the non-condensable gas generation produced only a smaller amount of gas, the containment pressure goes down.

As shown in Fig. 12, the hydrogen generation increases significantly around 4 hours. This is because the fuel temperatures in the core reach elevated levels allowing significant oxidation. The short term station black out develops very quickly. After 7 hours the vessel fails, and all the materials fall out of the vessel. At this point, the accumulated hydrogen mass reaches its peak during the whole accident. 


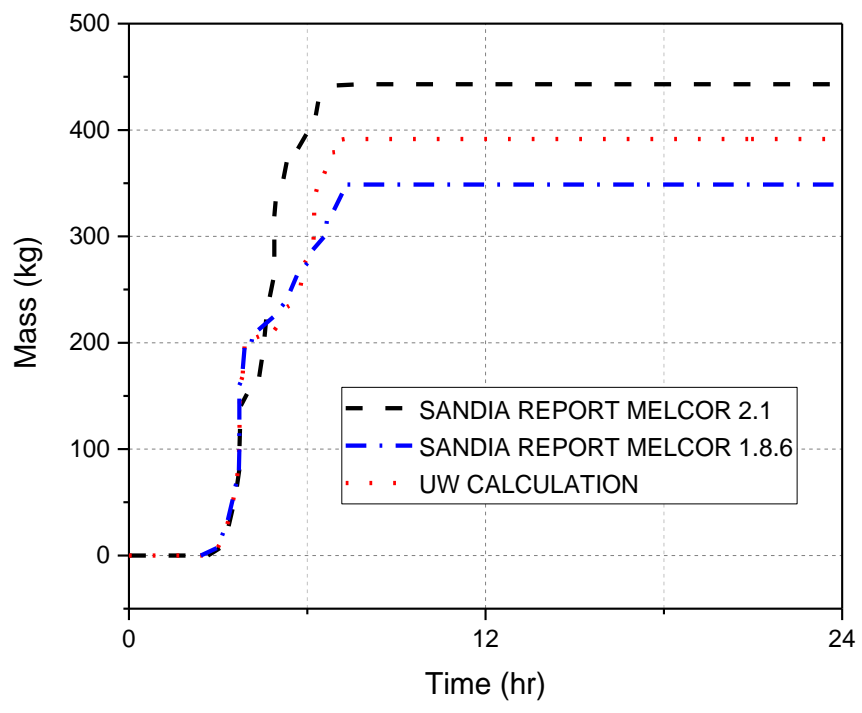

Fig. 12 Mass of Hydrogen

\section{Thermo-physical Properties, Oxidation Kinetics, and other Advantages of FeCrAl}

\section{Thermo-physical Properties}

Benefits from US Department of Energy's effort, enhancing the accident tolerance of light water reactors became a hot topic in the US congress. A lot of experiment and simulation research projects are conducted in United States. Through vast literature review (Ott, et al., 2014; Merill, et al., 2015; Farmer et al., 2014; Massey, et al., 2016), ORNL research of $\mathrm{FeCrAl}$ (and $\mathrm{FeCrAl}$ oxide) was found pertaining to many thermosphysical properties: enthalpy, specific heat, thermal conductivity, density, melting temperature, and latent heat of fusion (as shown in Fig.13-18). Enthalpy of FeCrAl (and FeCrAl oxide) constantly increases along with the increase of temperature. As shown in Fig.13, the relationship between enthalpy and temperature is almost linear except between 1500k and 2000K. 


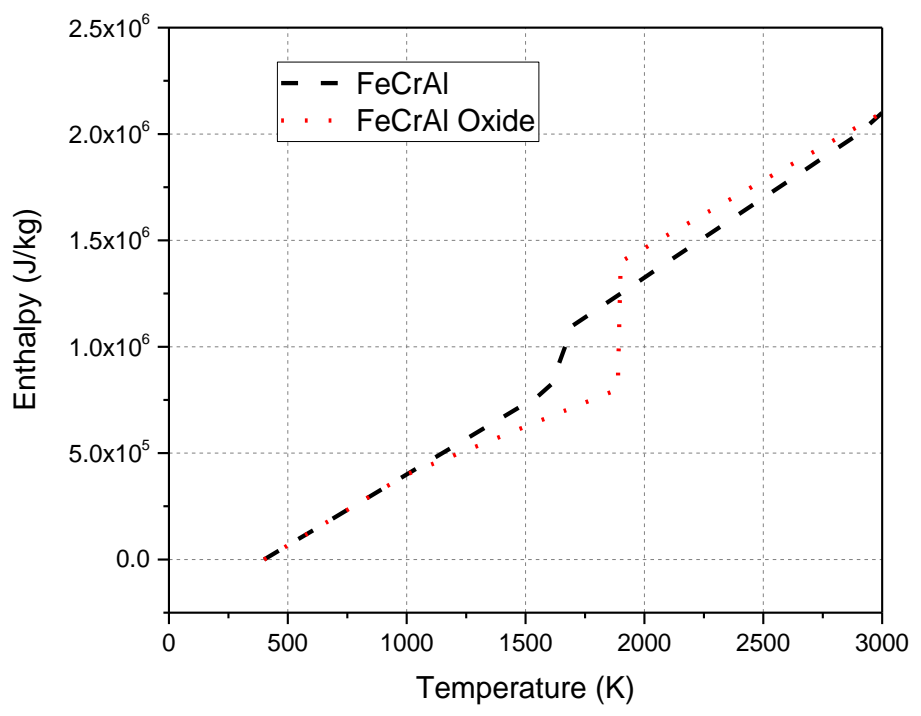

Fig.13 Enthalpy

When temperature is below $1500 \mathrm{~K}$, the relationship between specific heat and temperature of $\mathrm{FeCrAl}$ is linear. Specific heat continuously increases along with the increase of temperature. When temperature is higher than $1500 \mathrm{~K}$, specific heat remains constant. On the other hand, specific heat of $\mathrm{FeCrAl}$ oxide is always a constant, which is always lower than specific heat of FeCrAl.

The trend of thermal conductivity is similar to specific heat. As shown in Fig.15, the relationship between thermal conductivity and temperature of FeCrAl is linear. When temperature is lower than $1800 \mathrm{~K}$, thermal conductivity continuously increases along with the increase of temperature. When temperature is higher than $1800 \mathrm{~K}$, thermal conductivity remains constant. Meanwhile, thermal conductivity of $\mathrm{FeCrAl}$ oxide is always a constant, and lower than FeCrAl. 


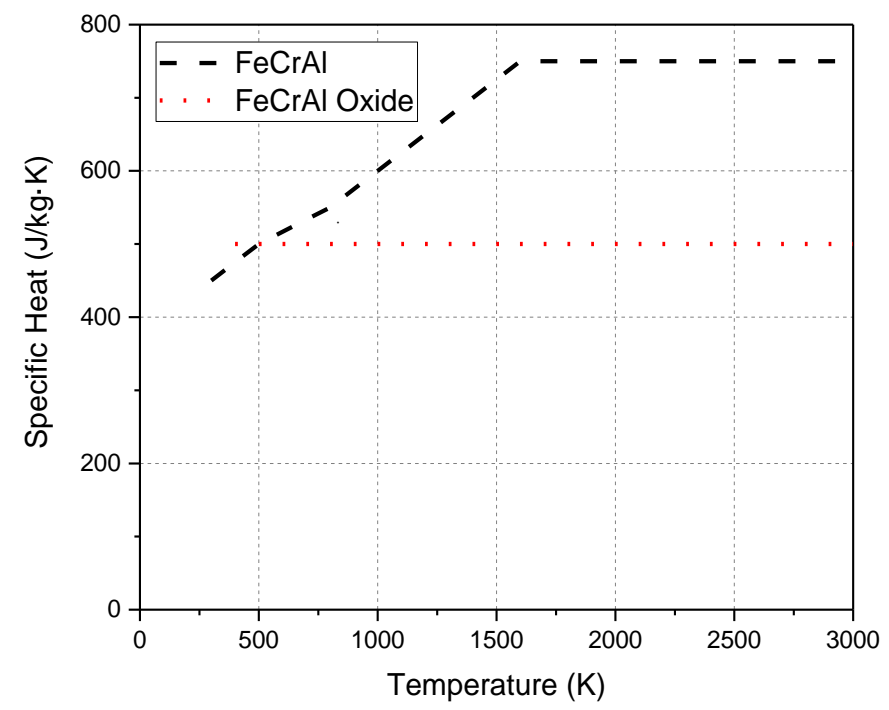

Fig.14 Specific Heat

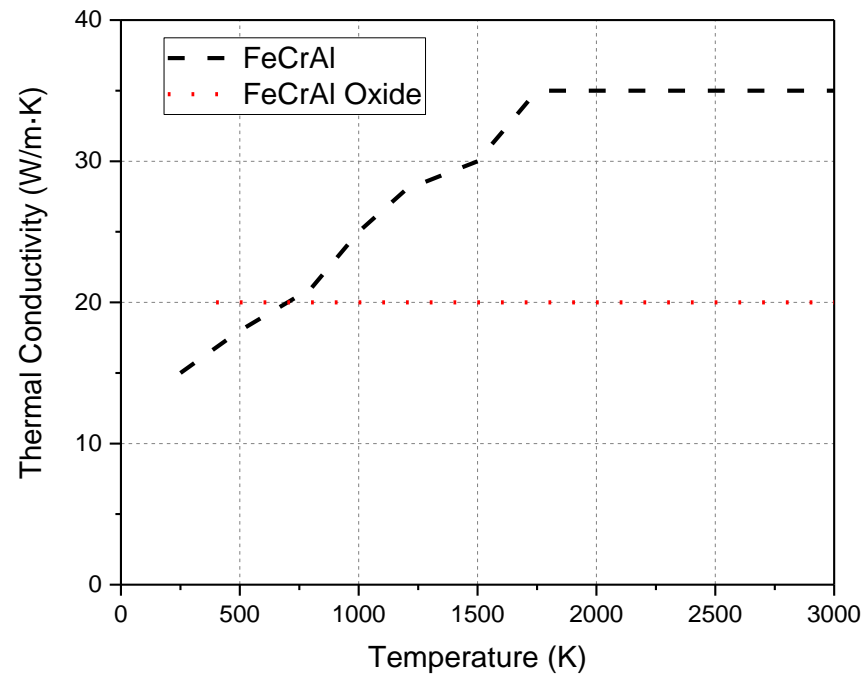

Fig.15 Thermal Conductivity

Density of FeCrAl changes from $8000 \mathrm{~kg} / \mathrm{m}^{3}$ to $7000 \mathrm{~kg} / \mathrm{m}^{3}$ as temperature changes from $300 \mathrm{~K}$ to $1500 \mathrm{~K}$. Then it remains $7000 \mathrm{~kg} / \mathrm{m}^{3}$ when temperature is higher than $1500 \mathrm{~K}$. Density of $\mathrm{FeCrAl}$ oxide is always $5000 \mathrm{~kg} / \mathrm{m}^{3}$ while temperature is between $500 \mathrm{~K}$ to $3000 \mathrm{~K}$, as presented in Fig.16. Fig.17 shows the melting temperature of FeCrAl and 
FeCrAl oxide. The melting temperature of $\mathrm{FeCrAl}$ is around $1600 \mathrm{~K}$, and the melting temperature of $\mathrm{FeCrAl}$ oxide is around $1800 \mathrm{~K}$.

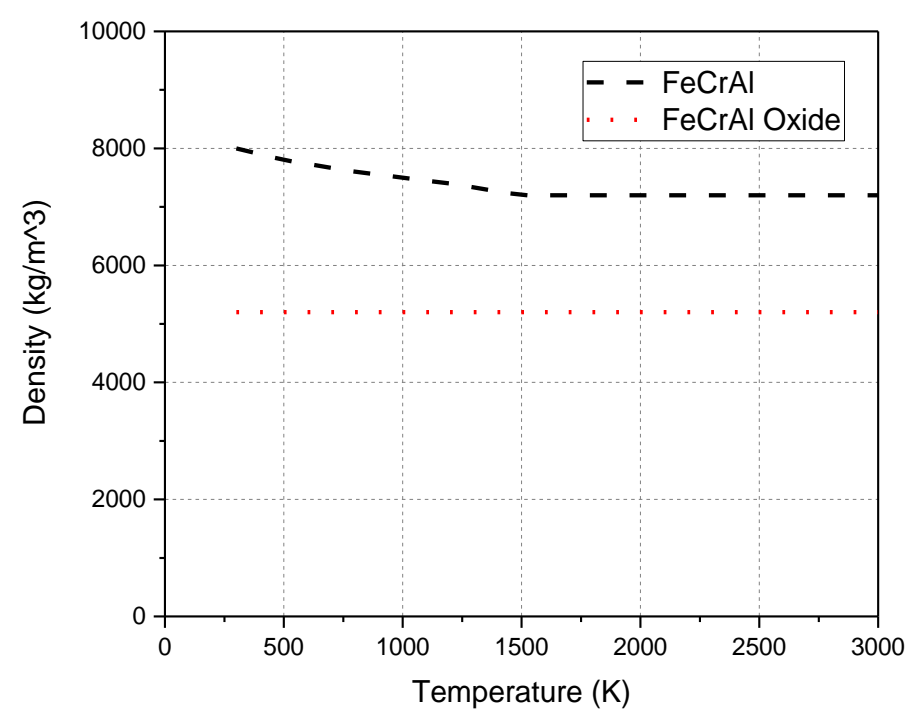

Fig.16 Density

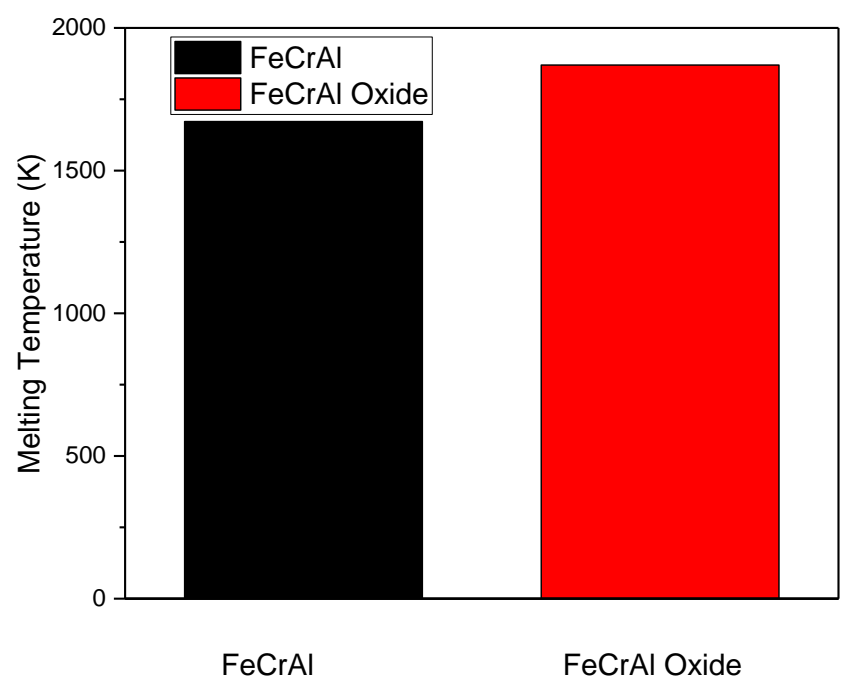

Fig.17 Melting Temperature

Fig.18 shows the fusion latent heat of $\mathrm{FeCrAl}$ and $\mathrm{FeCrAl}$ oxide. The latent heat of fusion of $\mathrm{FeCrAl}$ is around $260 \mathrm{~kJ} / \mathrm{kg}$, and the latent heat of fusion of $\mathrm{FeCrAl}$ oxide is around $580 \mathrm{~kJ} / \mathrm{kg}$. 


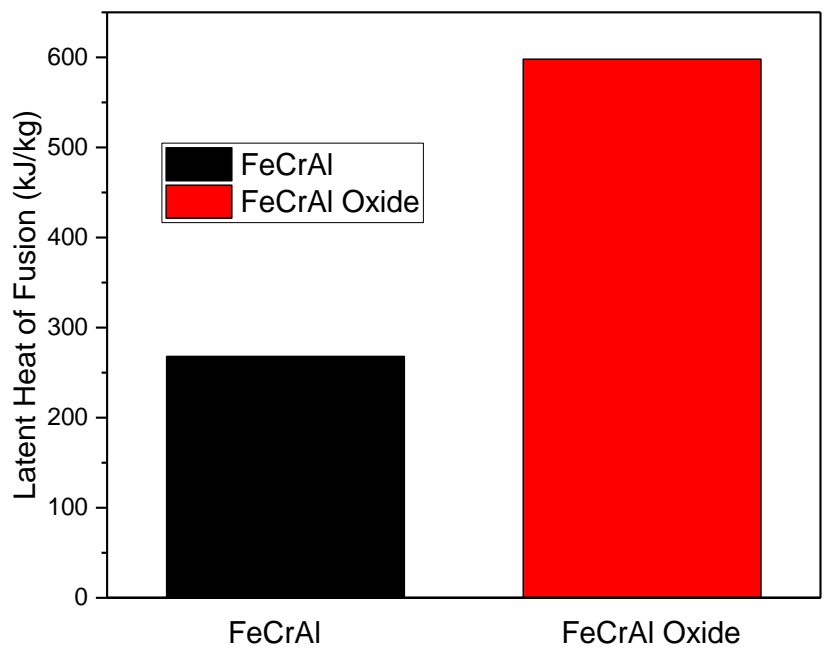

Fig.18 Latent Heat of Fusion

\section{Oxidation Kinetics}

Oxidation Kinetics of $\mathrm{FeCrAl}$ is similar to Zircaloy. The oxidation parabolic equation is also described as:

$$
\begin{gathered}
x^{2}=k_{p} t \\
k_{p}=k_{0} \times e^{\left(\frac{-E_{a}}{R T}\right)}
\end{gathered}
$$

Where $k_{p}(\mu \mathrm{m} 2 / \mathrm{h})$ is the parabolic rate constant; $k_{o}$, is the a pre-exponential constant; $\mathrm{R}$ is the universal gas constant $(\mathrm{J} / \mathrm{mol}-\mathrm{K}) ; E_{a}$ is the activation energy $(\mathrm{J} / \mathrm{mol}) ; \mathrm{x}$ is oxide thickness. The log parabolic rate constant is shown as Fig.19. The number of $k_{o p, H 2 O}$ of $5.213 \times 10-1\left(\mathrm{~kg}^{2}-\mathrm{FeCrAl} / \mathrm{m}^{4}-\mathrm{s}\right)$ and an $E_{a, H 2 O}$ of $260(\mathrm{~kJ} / \mathrm{mol}-\mathrm{K})$ for steam can be acquired from this figure and directly used in MELCOR modification. 


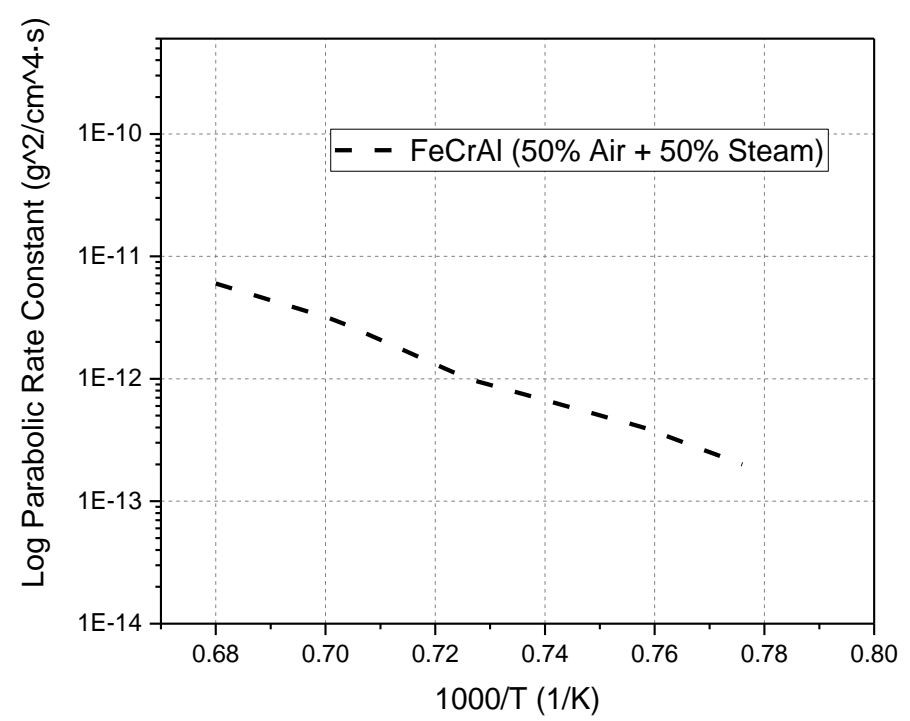

Fig19. FeCrAl oxidation data for steam

Due to the protection of $\mathrm{Al}, \mathrm{FeCrAl}$, better prevents hydrogen generation. For an experienced expert, the parabolic equation can show the Oxidation Kinetics of FeCrAl. To show it more clearly, researchers from ORNL also compared the hydrogen generation between zircaloy and some ATF materials (Pint et al). As seen in Fig.20, FeCrAl significantly reduces the hydrogen production.

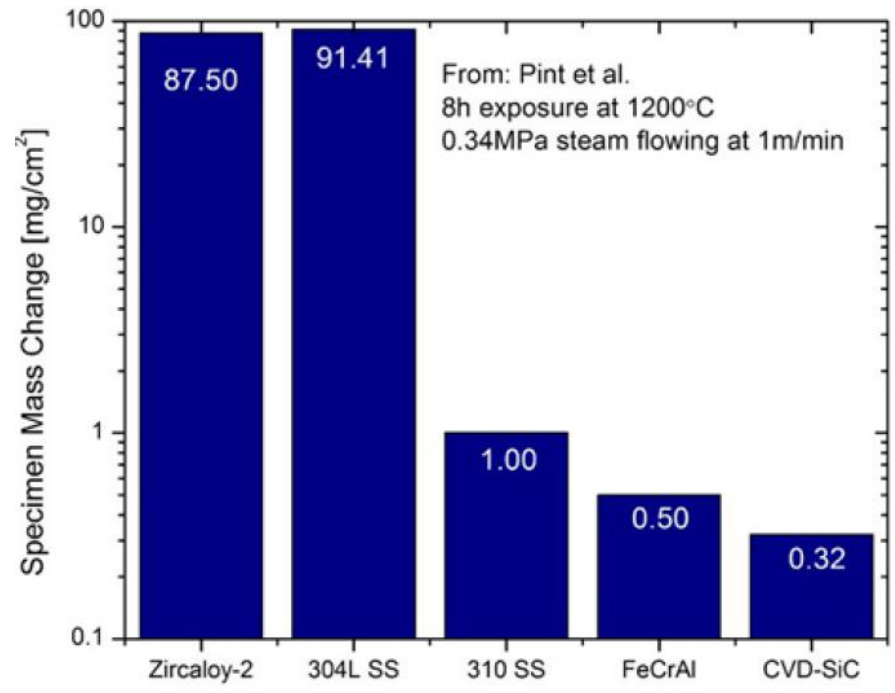

Fig.20 Oxidation mass Change Comparison 


\section{Better Mechanical Properties}

Cladding burst behavior is studied by Massey et al., as shown in Fig.22. From this figure, we can see that Zircaloy cannot withstand the temperature which is higher than $1200 \mathrm{~K}$. However, if Zircaloy is replaced by $\mathrm{FeCrAl}$, the clad will be able to withstand a temperature of $1500 \mathrm{~K}$. This difference can observably slow down severe accident process and reduce severe accident effects.

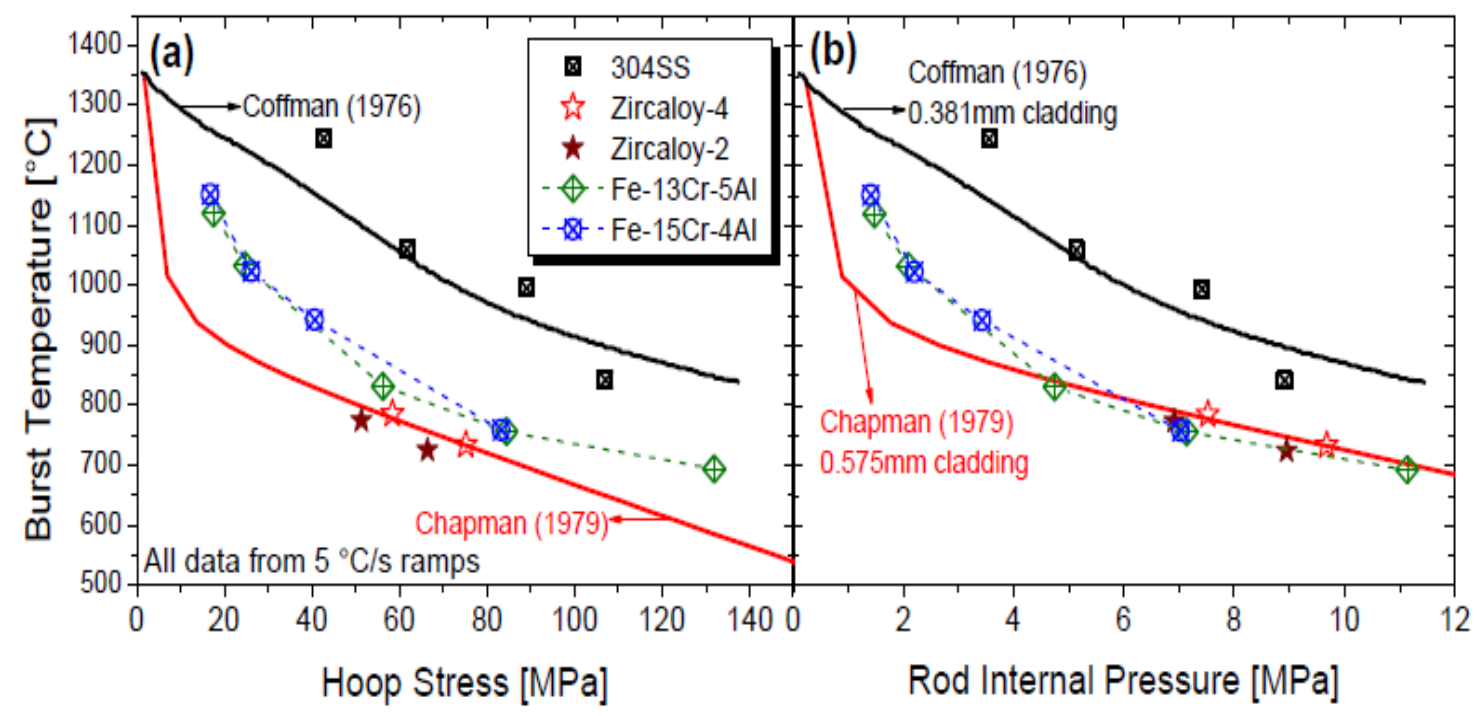

Fig.22 Burst Temperature of Clad Materials

\section{FeCrAl Performances during the STSBO Event}

\section{Thermo-physical Properties and Oxidation Kinetics Edition in MELCOR}

To examine the material performance of $\mathrm{FeCrAl}$, the thermo-physical properties of Zircaloy and Zircaloy oxide were replaced with $\mathrm{FeCrAl}$ and $\mathrm{FeCrAl}$ Oxide in MELCOR. These properties included: ENH (Temperature VS Enthalpy), CPS (Specific Heat), THC (Thermal Conductivity), RHO (Density), MLT (Melting Temperature), LHF (Latent Heat of Fusion). The Oxidation Parabolic Equation was also updated for FeCrAl. The $\mathrm{k}_{\mathrm{o}}$ is 0.5213, and $E_{a}$ is 260000. The clad thickness stayed the same (Merrill, Bragg-Sitton, 
2013 a). Due to density different, mass of FeCrAl clad increases; this difference was also considered in the new version.

Oxidation energy is an important output along with the process of zircaloy-steam oxidation. An analysis on this situation can help the understanding of oxidation kinetic. (EI-Wakil, 1971) Chemical equation of zircaloy-steam oxidation can be described as:

$$
\mathrm{Zr}+2 \mathrm{H}_{2} \mathrm{O} \rightarrow \mathrm{ZrO}_{2}+2 \mathrm{H}_{2}
$$

Due to the analysis of enthalpy, we can see that each appear of 1 mole $\mathrm{H} 2$ will along with $307 \mathrm{~kJ}$, which means the percent conversion is $1.53 \times 10^{\wedge} 5 \mathrm{~kJ} / \mathrm{kg}$.

For the oxidation reaction between $\mathrm{FeCrAl}$ and steam, Aluminum is the main reactant with steam, so only the following chemical equation is considered:

$$
2 \mathrm{Al}+3 \mathrm{H}_{2} \mathrm{O} \rightarrow \mathrm{Al}_{2} \mathrm{O}_{3}+3 \mathrm{H}_{2}
$$

Due to the analysis of enthalpy, we can see that each appear of 1 mole $\mathrm{H} 2$ will along with $307 \mathrm{~kJ}$, which means the percent conversion is $1.58 \times 10^{\wedge} 5 \mathrm{~kJ} / \mathrm{kg}$. Based on the analysis above, we know that if there is hydrogen generation mass of each reaction, we can calculate the oxidation energy of each reaction, as shown in Fig.23.

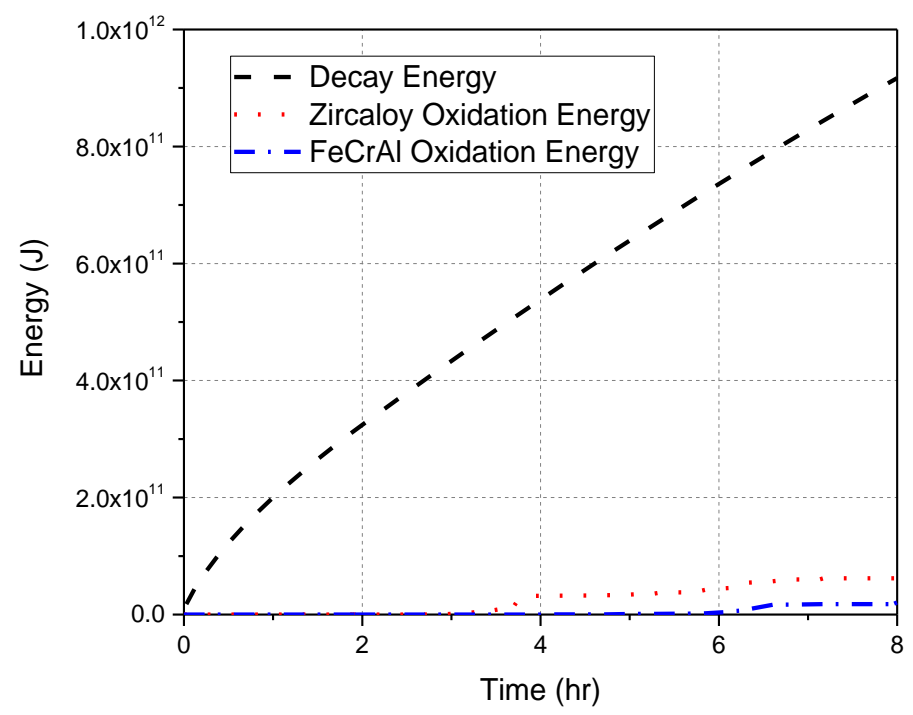

Fig.23 Energy Comparison of Decay Energy and Oxidation Energy 
This can prove that the oxidation energy is important but not the most important energy. If we did not consider the change of oxidation energy, the result will not be different too much. In addition, since $\mathrm{FeCrAl}$ produce less hydrogen, if we did not change the oxidation energy, we will over predict the production of hydrogenation mass. So our result can meet the safety demand.

\section{MELCOR Calculation Results and Analysis}

When Zircaloy is replaced by FeCrAl, the steam generator seems work better and a little longer. At the time of 1 hour and 15 minutes, the primary loop pressure is lower than the similar situation for Zircaloy. After 4 hours, the secondary loop pressure of the FeCrAl clad case is also lower than Zircaloy clad case.

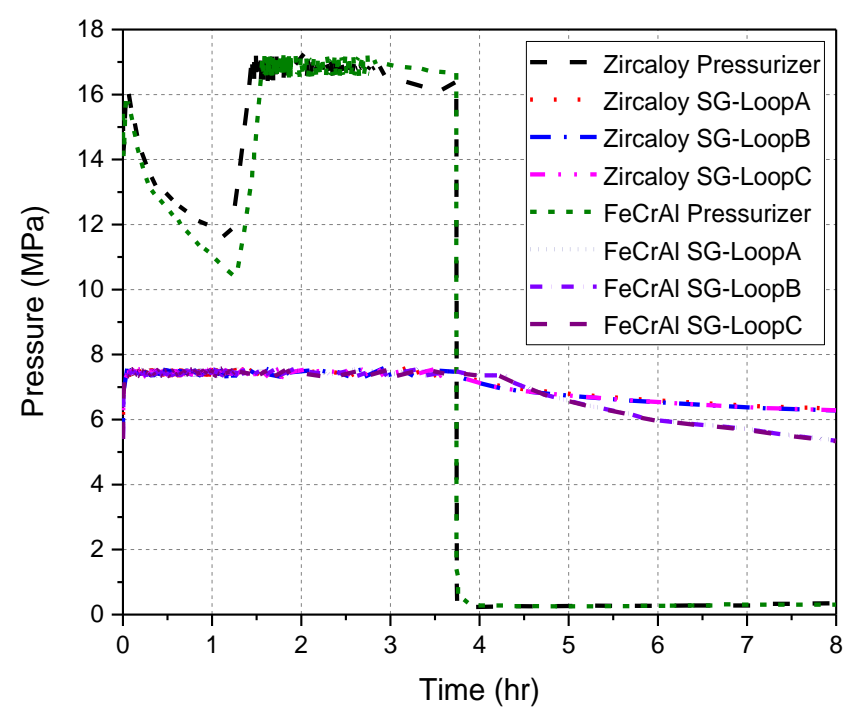

Fig.24 Primary and Secondary Pressure (Comparison) 


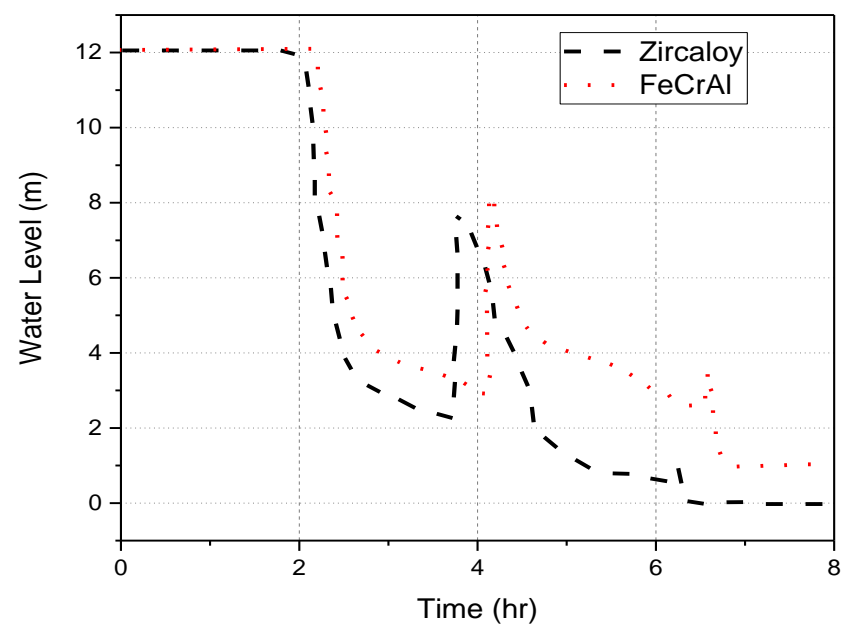

Fig.25 Vessel Water Level (Comparison)

The trend of the vessel water level of FeCrAl is almost same as the Zircaloy clad case. However, it is always higher than the former Zircaloy clad case; which means the core can have more cooling water to relieve severe accident process. This difference proves FeCrAl could provide a safer option for current operation of nuclear power plants.

At the start of STSBO event, the core temperature still stays low. FeCrAl and Zircaloy thermo-physical properties remain similar in such a situation. Thus, the down-comer water level slowly, but constantly, decreases in both cases.

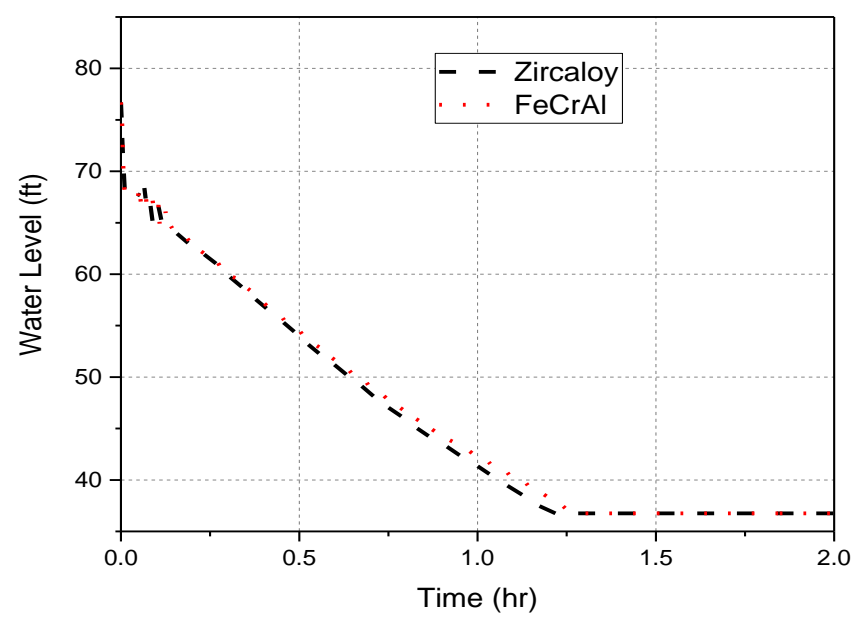

Fig.26 SG Down-comer Water Level (Comparison) 


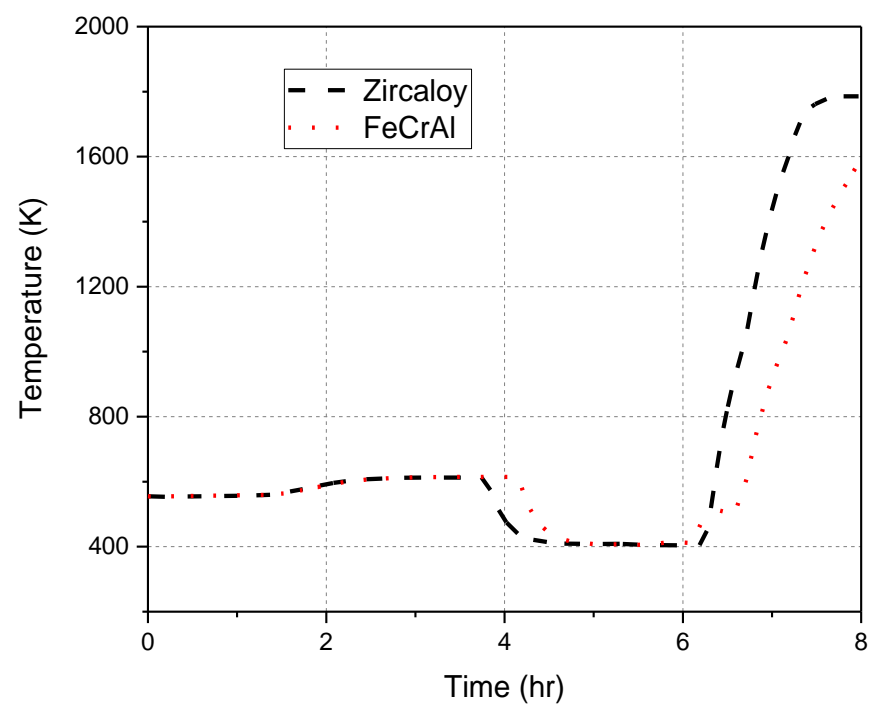

Fig.27 Low Head Temperature (Comparison)

For the lower head temperature, before 6 hours, the trend of FeCrAl case and Zircaloy keep similar. After that, the temperature of FeCrAl significantly increases more slowly. At 8 hours, low head temperature of Zircaloy reaches $1800 \mathrm{~K}$, while the low head temperature of $\mathrm{FeCrAl}$ is still below $1600 \mathrm{~K}$.

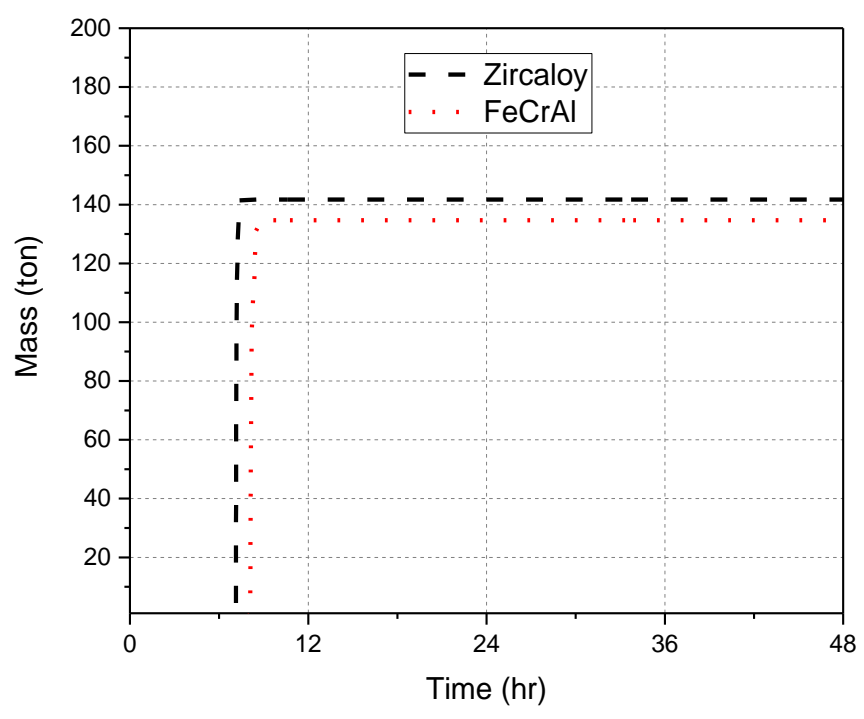

Fig.28 Debris Mass Through Vessel (Comparison) 
For both calculations, the debris mass through vessel is around 140 tons. The debris mass in Zircaloy case is a little higher than 140 tons, while the debris in FeCrAl case is a little lower than 140 tons. In the Zircaloy case the time for debris mass through the vessel is around 7 hours, but in the $\mathrm{FeCrAl}$ case this time is around 8 hours. FeCrAl delays the failure of reactor vessel 1 hour.

The most significantly difference between the two calculations is total hydrogen mass in the core. As seen in Fig. 29, the total core hydrogen mass of the Zircaloy case is around $400 \mathrm{~kg}$. However, in the $\mathrm{FeCrAl}$ case, this number is just around $140 \mathrm{~kg}, 65 \%$ different. In addition, the significant increase of hydrogen production in Zircaloy starts at 4 hours. But in the $\mathrm{FeCrAl}$ case, this time is around 6 hours; which is a huge relief of severe accident process. This result proves that $\mathrm{FeCrAl}$ is a good potential accident tolerant clad material. Containment pressure of both calculations are almost same.

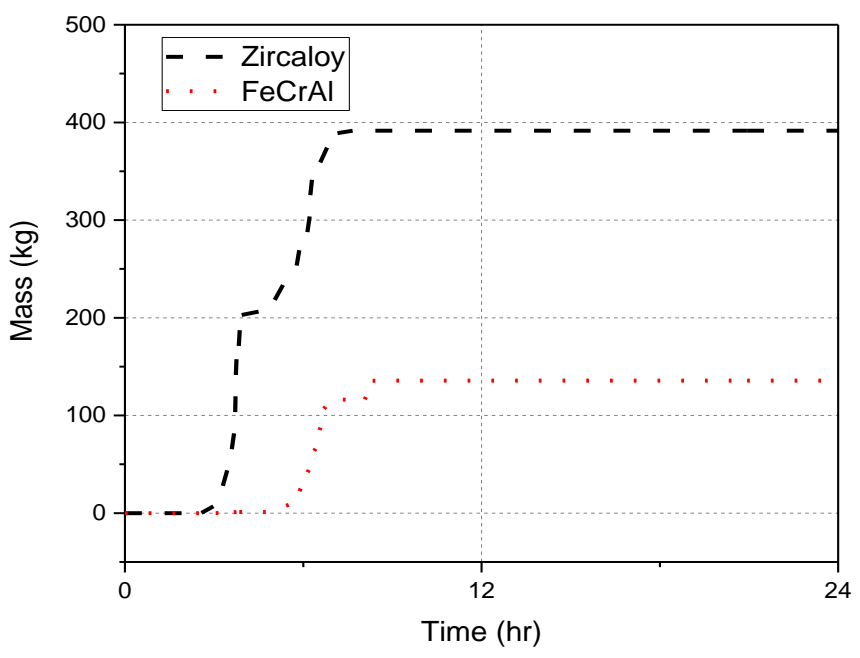

Fig.29 Total Hydrogen Mass (Comparison) 


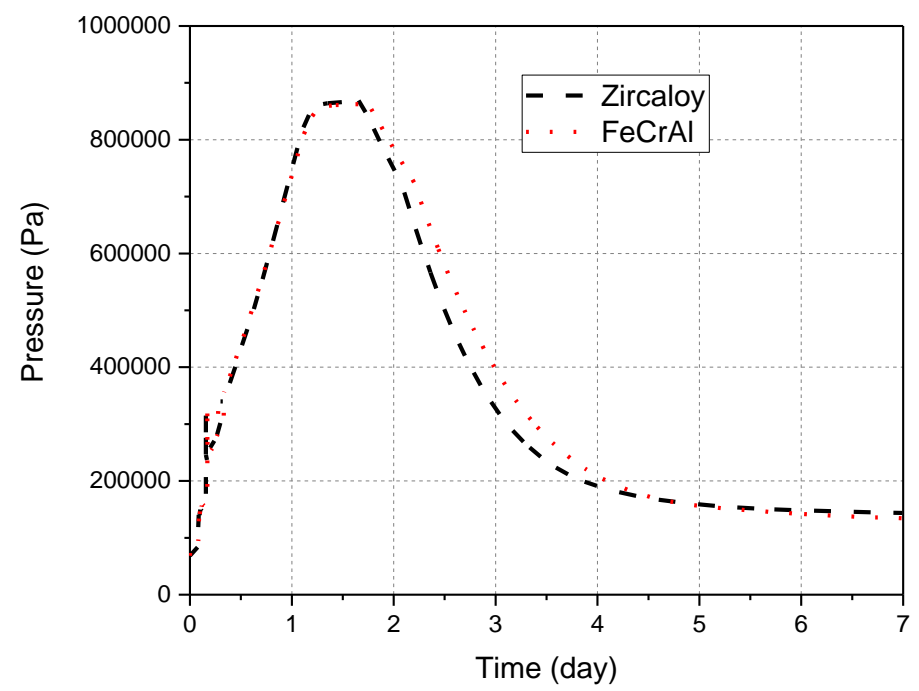

Fig.30 Containment Pressure (Comparison)

The core clad temperatures are shown in the following figures. The first figure shows clad temperature history in 9 core cells. And the second figure shows a comparison between the Zircaloy case and the $\mathrm{FeCrAl}$ case. The peak temperature for the FeCrAl case occurs 1.5 hours later than the Zircaloy case.

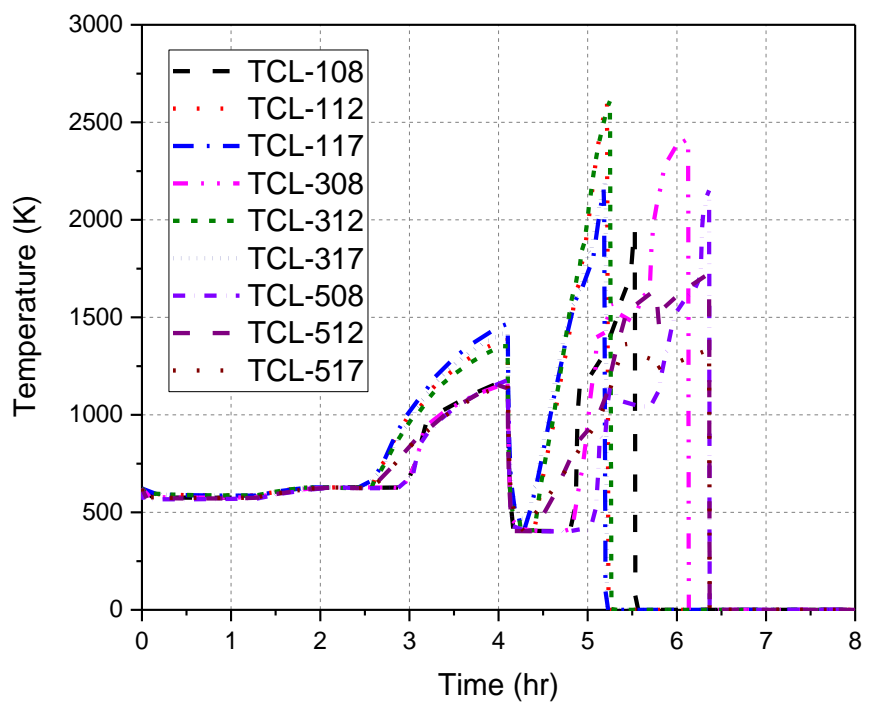

Fig.31 Core Clad Temperature 


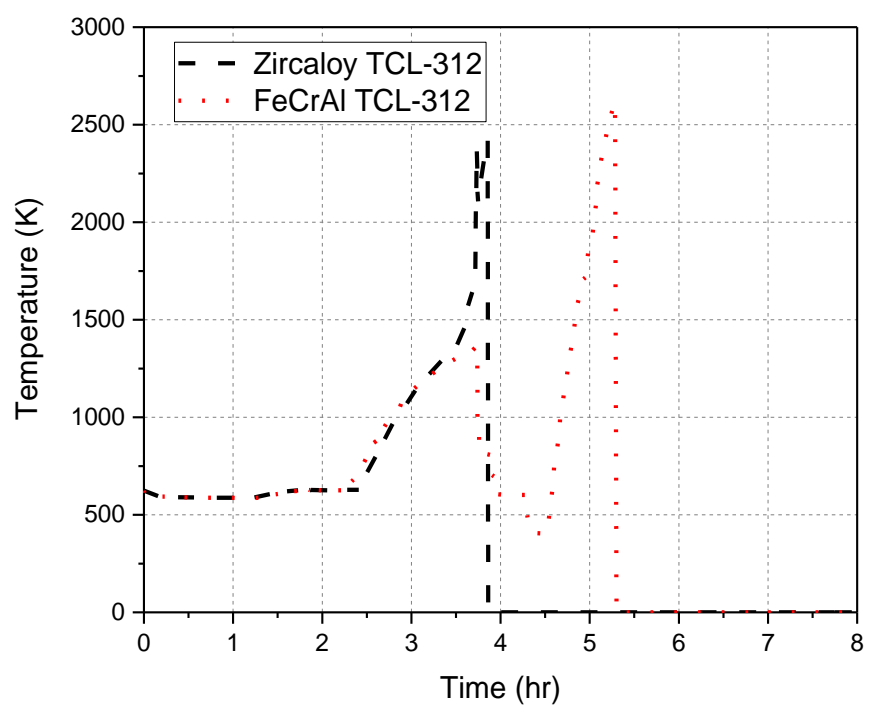

Fig.32 Core Clad Temperature (Comparison)

As we can see from current result, while Zircaloy is replaced by FeCrAl, most thermal hydraulic calculations will stay the same. The most significant change is the hydrogen generation mass. Shown in Fig.29, the start time of hydrogen generation is 2 hours later when Zircaloy is replaced by $\mathrm{FeCrAl}$, and the hydrogen production mass is $65 \%$ less. As shown in Fig. 28, the failure time of lower plenum vessel is an hour later when Zircaloy is replaced by $\mathrm{FeCrAl}$.

\section{Conclusion}

Our research team (MIT, UW-Madison, Texas A\&M, AREVA and Westinghouse) supported by DOE Integrated Research Project (IRP) focused on development of accident tolerant fuel-clad options for near-term applications. At UW-Madison, as part of this work, we are examining fuel performance modeling for a range of accidents using the MELCOR systems code. This work initially has used SURRY as its model plant and the STSBO as the initial accident to consider. The analysis uses MELCOR, Version 1.8.6 (YR), which is a special version developed by Idaho National Laboratory in collaboration with MELCOR developers at Sandia National Laboratories. This version allows the user to alter the cladding material considered, and our study examines the behavior of the 
$\mathrm{FeCrAl}$ alloy as a substitute for Zircaloy. Our benchmark comparisons with the SOARCA analysis using MELCOR 1.8.6 and the more recent MELCOR 2.1 indicate good overall agreement through the early phases of the severe accident progression.

Following this benchmarking exercise, we examined the effect of substituting a candidate metallic alloy, FeCrAl, for Zircaloy as a cladding material. We used the generic properties for $\mathrm{FeCrAl}$ as available in research literature, as well as the simplified oxidation kinetics suggested by Merrill et al (2013a,b). When FeCrAl is substituted for Zircaloy to examine its performance, we confirmed that FeCrAl can slow the accident progression and reduce the amount of hydrogen generated, due to the slower oxidation kinetics for this metallic alloy. Further investigations are needed for $\mathrm{FeCrAl}$ to examine the effect of uncertainties on the oxidation kinetics. However, our analyses also show that MELCOR can be used to evaluate other potential ATF cladding materials as methods to delay deleterious effects of fuel degradation, e.g., $\mathrm{SiC}$ as well as innovative coatings on zirconium cladding alloys, $\mathrm{Cr}, \mathrm{ZrSi}$, TiAlC, and TiSiC. This ATF performance analysis platform will also be used to support experimental work underway in this IRP by our team members.

7.Acknowledgements: We wish to recognize support from U.S. DOE for our work. Thanks to Dr. Merrill and Humrickhouse at INL for providing the MELCOR input. Thanks to Dr. Robb at ORNL for providing oxidation kinetic technology support. Thanks for the support from Professor Sridharan (University of Wisconsin-Madison) and to Prof. Buongiorno and Dr. Shirvan (MIT) for coordination.

\section{References}

1. Bixler, N.E., Brewer, J.D., Gauntt, R.O., 2008. State-of-the-Art Reactor Consequence Analysis (SOARCA) Project Best Modeling Practices Volume IV. NUREG-XXX

2. SAND2008P-XXX.

3. Bragg-Sitton, S., 2014. Development of advanced accident-tolerant fuels for commercial LWRs. Nuclear News, 83-91. 
4. Brown, N.R., Aronson, A., Todosow, M., Brito, R., McClellan, K.J., 2014. Neutronic performance of uranium nitride composite fuels in a PWR. Nuclear Engineering and Design 275, 393-407.

5. Carbajo, J.J., 1994. MELCOR sensitivity studies for a low-pressure, short-term station blackout at the Peach Bottom plant. Nuclear engineering and design 152, 287317.

6. Carmack, J., Goldner, F., 2014. Forward for special JNM issue on accident tolerant fuels for LWRs. Journal of Nuclear Materials 1, 373.

7. Carmack, J., Goldner, F., Bragg-Sitton, S.M., Snead, L.L., 2013. Overview of the US DOE accident tolerant fuel development program. Top Fuel 2013, 16-20.

8. Einziger, R.E., 1988. Test plan for thermogravimetric analyses of BWR spent fuel oxidation. Battelle Pacific Northwest Laboratories.

9. EI-Wakil, M.M., 1971. Nuclear Heat Transport, International Textbook Company, Scranton, PA

10. Farmer, M., Leibowitz, L., Terrani, K.A., Robb, K.R., 2014. Scoping assessments of ATF impact on late-stage accident progression including molten core-concrete interaction. Journal of Nuclear Materials 448, 534-540.

11. Gauntt, R., 2005. MELCOR Computer Code Manuals, Vol. 1: Primer and Users' Guide, Version 1.8. 6 September 2005. Sandia National Laboratories Albuquerque, NM, 87185-80739.

12. kazimi, M., 2015. Development of Accident Tolerant Fuel Options for Near Term Applications. Nuclear Energy University Program, U.S., Department of Energy.

13. Lauf, R., Lindemer, T., Pearson, R., 1984. Out-of-reactor studies of fission productsilicon carbide interactions in HTGR fuel particles. Journal of nuclear materials 120, 6-30.

14. Lee, Y., Kazimi, M.S., 2015. A structural model for multi-layered ceramic cylinders and its application to silicon carbide cladding of light water reactor fuel. Journal of Nuclear Materials 458, 87-105.

15. Massey, C.P., Terrani, K.A., Dryepondt, S.N., Pint, B.A., 2016. Cladding burst behavior of Fe-based alloys under LOCA. Journal of Nuclear Materials 470, 128-138. 
16. Merrill, B.J., Bragg-Sitton, S.M., 2013a. SiC Modifications to MELCOR for Severe Accident Analysis Applications. Idaho National Laboratory (INL).

17. Merrill, B.J., Bragg-Sitton, S.M., 2013b. Status Report on Advanced Cladding Modeling Work to Assess Cladding Performance Under Accident Conditions. INL/EXT-13-30206, September.

18. Ott, L.J., Robb, K.R., Wang, D., 2014. Preliminary assessment of accident-tolerant fuels on LWR performance during normal operation and under DB and BDB accident conditions. Journal of Nuclear Materials 448, 520-533.

19. Pint, B.A., Terrani, K.A., Brady, M.P., Cheng, T., Keiser, J.R., 2013. High temperature oxidation of fuel cladding candidate materials in steam-hydrogen environments. Journal of Nuclear Materials 440, 420-427.

20. Stempien, J.D., 2011. Behavior of triplex silicon carbide fuel cladding designs tested under simulated PWR conditions. Massachusetts Institute of Technology.

21. Terrani, K.A., Parish, C.M., Shin, D., Pint, B.A., 2013. Protection of zirconium by alumina-and chromia-forming iron alloys under high-temperature steam exposure. Journal of Nuclear Materials 438, 64-71.

22. Wang, J., Corradini, M.L., Fu, W., Haskin, T., Tian, W., Zhang, Y., Su, G., Qiu, S., 2014. Comparison of CORA \& MELCOR core degradation simulation and the MELCOR oxidation model. Nuclear Engineering and Design 276, 191-201.

23. Wang, J., Zhang, Y., Mao, K., Huang, Y., Tian, W., Su, G., Qiu, S., 2015a. MELCOR simulation of core thermal response during a station blackout initiated severe accident in China pressurized reactor (CPR1000). Progress in Nuclear Energy 81, 6-15.

24. Wang, M., Zhao, H., Zhang, Y., Su, G., Tian, W., Qiu, S., 2012. Research on the designed emergency passive residual heat removal system during the station blackout scenario for CPR1000. Annals of Nuclear Energy 45, 86-93.

25. Wang, X., Jamison, L., Sridharan, K., Morgan, D., Voyles, P., Szlufarska, I., $2015 b$. Evidence for cascade overlap and grain boundary enhanced amorphization in silicon carbide irradiated with $\mathrm{Kr}$ ions. Acta Materialia 99, 7-15.

26. Wu, X., Kozlowski, T., Hales, J.D., 2015. Neutronics and fuel performance evaluation of accident tolerant FeCrAl cladding under normal operation conditions. Annals of Nuclear Energy 85, 763-775. 
27. Youinou, G., Sen, R.S., 2013. Enhanced Accident Tolerant Fuels for LWRs-A Preliminary Systems Analysis. Tech. Rep.

28. Zinkle, S.J., Terrani, K.A., Gehin, J.C., Ott, L.J., Snead, L.L., 2014. Accident tolerant fuels for LWRs: A perspective. Journal of Nuclear Materials 448, 374-379. 